\title{
PERBANDINGAN BLENDED LEARNING DAN FACE-TO- FACE LEARNING TERHADAP KEMAMPUAN KOMUNIKASI MAHASISWA PADA PROYEK DESAIN WEBSITE
}

\author{
Febrianto Sabirin $^{1}$, Dewi Sulistiyarini ${ }^{2}$ \\ ${ }^{1,2}$ Program Studi Pendidikan Teknologi Informasi dan Komputer, Fakultas Pendidikan MIPA dan \\ Teknologi, IKIP PGRI Pontianak, Jalan Ampera Nomor 88, Pontianak \\ e-mail: rinakasaka@gmail.com
}

\begin{abstract}
Abstrak
Penelitian bertujuan untuk mengetahui perbedaan kemampuan komunikasi mahasiswa setelah melaksanakan proyek pembuatan desain website menggunakan model pembelajaran Blended Learning (BL) dan pembelajaran tatap muka/face-to-face (F2F). Metode penelitian yang digunakan adalah metode eksperimen dengan bentuk penelitian adalah kuasi eksperimen. Populasi penelitian berjumlah 696 mahasiswa dan sampel penelitian berjumlah 63 mahasiswa yang diambil menggunakan teknik purposive sampling. Sampel penelitian dibagi menjadi dua kelas, yaitu kelas yang melaksanakan BL dan kelas yang melaksanakan pembelajaran F2F. Alat pengumpul data dalam penelitian ini berupa portofolio dan lembar observasi. Teknik analisis data menggunakan analisis deskriptif dan analisis multivariat. Hasil analisis menunjukkan bahwa kemampuan komunikasi mahasiswa berada dalam kategori baik dan terdapat perbedaan kemampuan komunikasi pada proyek desain website antara kelompok yang melaksanakan BL dan F2F.
\end{abstract}

Kata Kunci: pembelajaran berbasis proyek, blended learning, komunikasi, desain website.

\begin{abstract}
The research aimed to determine differences in student communication skills after implementing a website design project using Blended Learning $(B L)$ learning model and face-to-face learning $(F 2 F)$. The research method used an experimental method with the form of research was quasi-experimental. The study population numbered 696 students and the study sample numbered 63 students taken using purposive sampling techniques. The research sample divided into two classes, namely classes that carry out BL and classes that carry out F2F learning. Data collection tools were in the form of portfolios and observation sheets. Data analysis techniques using descriptive analysis and multivariate analysis. The analysis showed that the communication skills of students are in good category and there are differences in communication skills in website design projects between groups implementing $B L$ and $F 2 F$.
\end{abstract}

Keywords: project-based learning, blended learning, communication, website design.

\section{PENDAHULUAN}

Dunia pendidikan khususnya pendidikan menengah dan tinggi harus menghasilkan lulusan yang mampu beradaptasi dengan RI 4.0 dan memiliki kombinasi keterampilan guna genghasilkan manusia yang mampu menjawab tantangan Revolusi Industri (RI) 4.0. Keterampilan yang diperlukan pada RI 4.0 adalah keterampilan pemecahan masalah yang kompleks, berpikir kritis, kreatif, 
manajemen, mampu berkoordinasi, kecerdasan emosi, pengambilan keputusan, berorientasi pada pelayanan, negosiasi, fleksibilitas kognitif, komunikasi, adaptasi, inisiatif, mengakses dan menganalisis informasi (World Economic Forum, 2016; Wagner, 2010).

Berbagai keterampilan tersebut tentunya perlu dikuasi oleh setiap lulusan dari pendidikan menengah dan tinggi termasuk lulusan pada Institut Keguruan dan Ilmu Pendidikan Persatuan Guru Republik Indonesia (IKIP PGRI) Pontianak. Keterampilan-keterampilan tersebut perlu ditanamkan sehingga lulusan dari IKIP PGRI Pontianak memiliki daya saing pada era RI 4.0. Untuk menanamkan keterampilan tersebut, dosen/tenaga pendidik dapat mengintegrasikan utamanya dalam kegiatan belajar mengajar baik di kelas ataupun di laboratorium.

Bobot dari masing-masing keterampilan tentunya berbeda pada masingmasing bidang keahlian/program studi di lingkungan IKIP PGRI Pontianak. Program Studi Pendidikan Teknologi Informasi dan Komputer (P.TIK) yang salah satu keahlian khususnya adalah menjadi seorang desainer website tentunya perlu memiliki beberapa keterampilan yang perlu dikembangkan. Salah satu keterampilan yang perlu dikembangkan untuk menjadi desainer website adalah kemampuan komunikasi (Ahmed and Capretz, 2012; Ahmed, et al., 2013; Udacity, 2017).

Kemampuan komunikasi secara tradisional dapat diartikan sebagai kemampuan untuk menyampaikan gagasan, pemikiran ataupun pesan melalui suatu media kepada seseorang/kelompok orang (Depari dalam Onong, 2000) dan komunikasi adalah proses yang didalamnya terdapat gagasan yang dikirimkan dari sumber kepada penerima dengan tujuan untuk merubah perilakunya (Rogers dalam Madjid, 2013).

Kemampuan komunikasi yang baik diperlukan oleh seorang desainer website/desainer softwarelfront end developer/UX developer dalam hubungan dengan tiga kelompok yaitu manejemen/atasan, rekan, dan pelanggan. Kemampuan komunikasi yang baik akan membantu desainer dalam menyampaikan tujuan/gagasan, kemajuan, ataupun permasalahan yang sedang dihadapi kepada manajemen ataupun rekan kerjanya. Kemampuan komunikasi 
yang baik akan membantu desainer menjadi pendengar yang baik, memahami keinginan, hingga mampu menyampaikan gagasan/ide yang dimiliki kepada pelanggan. Kemampuan komunikasi tim yang efektif merupakan keterampilan yang penting untuk kesuksesan karier, sehingga kemampuan komunikasi yang baik dan didukung dengan keterampilan teknis (hard skills) akan membantu desainer website meraih kesuksesan jangka panjang (Kashefi, et al., 2012).

Desainer website dengan kemampuan komunikasi yang baik dapat dihasilkan melalui suatu metode yang membantu mahasiswa untuk meningkatkan kemampuan komunikasi. Menurut berbagai penelitian yang telah dilakukan menunjukkan bahwa pembelajaran berbasis proyek merupakan suatu model pembelajaran yang dapat meningkatkan ataupun memberikan pengaruh yang positif terhadap kemampuan komunikasi (Kovalyova, et al., 2016; Musa, et al., 2012; Eggleston and Rabb, 2018). Dalam pembuatan desain website sangatlah sesuai dengan model pembelajaran berbasis proyek yang menekankan produk sebagai hasil akhirnya. Proses peningkatan kemampuan komunikasi pada proyek desain website terjadi dengan adanya komunikasi dengan dosen/fasilitator, teman satu kelompok, teman satu kelas, dan subjek proyek. Komunikasi yang terjadi selama kegiatan proyek dapat berupa komunikasi secara lisan dalam bentuk diskusi atau presentasi maupun komunikasi secara tulisan melalui pembuatan portofolio, surat-menyurat, dan laporan.

Beberapa penelitian menunjukkan bahwa pembelajaran berbasis proyek mampu meningkatkan kemampuan komunikasi siswa. Namun, bukan berarti pembelajaran berbasis proyek tidak punya kendala dalam implementasinya. Salah satu permasalahan yang sering dialami guru atau dosen dalam menerapkan model pembelajaran adalah waktu pengerjaan yang cukup lama terutama pada proyekproyek dengan kompleksitas tinggi. Salah satu permasalahan dalam pembelajaran berbasis proyek adalah manajemen waktu (Trisdiono, 2014; Sumarni, 2015; Afriana, et al., 2016; Lesmana dan Arpan, 2017). Manajemen waktu diperlukan oleh dosen atau fasilitator untuk mengawal kemajuan proyek, sehingga proyek yang telah ditetapkan diawal dapat diselesaikan sesuai dengan standar yang telah diharapkan. 
Solusi yang diberikan untuk mengatasi kendala yang ada dalam pembelajaran berbasis proyek adalah dengan mengintegrasikan blended learning (BL). BL memberikan fleksibilitas waktu, tempat, dan media untuk belajar tanpa mengabaikan kebutuhan sosial siswa (Vernandakis, et al., 2012; Abbas, 2015; Harahap, et al., 2019). Melalui BL siswa juga dilatih untuk aktif, mandiri, dan bertanggung jawab terhadap tugas-tugas yang diberikan (Snodin, 2013). Artinya penerapan proyek desain website melalui BL akan memotivasi siswa untuk aktif, mandiri, dan bertanggung jawab terhadap proyek desain website tanpa terbatas waktu, tempat, dan media yang digunakan.

Hasil penelitian lain menyatakan bahwa BL memiliki potensi untuk memperkuat inti dari proses belajar-mengajar dan memiliki dampak positif pada kehidupan sehari-hari mahasiswa (Morton, et al., 2016). BL tidak hanya meningkatkan kualitas proses belajar-mengajar, tetapi juga mendukung kemampuan yang dibutuhkan sehari-hari seperti komunikasi. Hal tersebut karena BL merupakan strategi yang menggabungkan pembelajaran face-to-face (F2F) dengan sistem e-learning (Zou, 2005; Ghahari, 2013). Akibatnya, BL dapat menggabungkan keuntungan dari pembelajaran $\mathrm{F} 2 \mathrm{~F}$ dan e-learning sehingga keuntungan sosial pada pembelajaran F2F dan keuntungan fleksibilitas dan belajar mandiri dari e-learning dapat diperoleh secara bersamaan.

Melalui BL, kemampuan komunikasi mahasiswa didapatkan pada face-toface di kelas maupun melalui forum diskusi di e-learning. Penggunaan BL tidak hanya membantu mahasiswa untuk memiliki kemampuan komunikasi secara langsung / F2F tetapi juga akan memfasilitasi mahasiswa menggunakan modulmodul komunikasi berbasis teknologi. Meskipun pengerjaan proyek desain website melalui BL menjanjikan berbagai kelebihan, akan tetapi pembelajaran secara BL perlu diteliti lebih lanjut. Hal tersebut bertujuan untuk mengetahui ada tidaknya pengaruh positif antara proyek website yang dilaksanakan secara BL terhadap kemampuan komunikasi mahasiswa dan mengetahui ada tidaknya perbedaan antara kemampuan komunikasi mahasiswa yang menerapkan proyek website secara F2F dengan mahasiswa yang menerapkan proyek secara BL. 
Berdasarkan fakta yang telah diuraikan, maka tujuan penelitian adalah untuk mengetahui perbedaan kemampuan komunikasi mahasiswa setelah melaksanakan proyek pembuatan desain website menggunakan model pembelajaran Blended Learning (BL) dan pembelajaran tatap muka/face-to-face (F2F).

\section{METODE}

Penelitian menggunakan metode penelitian eksperiman. Bentuk eksperimen yang digunakan adalah kuasi eksperimen, mengingat peneliti tidak dapat mengontrol seluruh variabel yang memengaruhi variabel penelitian. Rancangan yang digunakan adalah desain faktorial dengan variabel bebas yaitu model pembelajaran BL dan F2F, dan variabel terikat adalah komunikasi lisan dan tulisan.

Populasi penelitian adalah 696 mahasiswa P.TIK IKIP PGRI Pontianak. Sampel penelitian berjumlah 63 mahasiswa yang diambil menggunakan teknik purposive sampling dengan pertimbangan yaitu mahasiswa mengambil mata kuliah Pemrograman Website dan pernah menerapkan pembelajaran berbasis proyek. Sampel penelitian dibagi menjadi dua kelompok yaitu kelompok yang mengerjakan proyek desain menggunakan F2F yang berjumlah 31 mahasiswa dan kelompok yang mengerjakan proyek desain web menggunakan BL yang berjumlah 32 mahasiswa.

Teknik pengumpulan data yang digunakan dalam penelitian adalah teknik pengukuran dan pengamatan. Alat pengumpul data dalam penelitian menggunakan portofolio dan lembar observasi. Penilaian kemampuan komunikasi dilakukan oleh dua orang dosen pengampu mata kuliah Pemrograman Website.

Aspek penilaian komunikasi pada penelitian didasarkan pada The 5 Inevitable Laws of Effective Communication, yaitu respect atau menghormati, emphaty atau empati, audible atau dapat didengar/dimengerti, clarity atau kejelasan, dan humble atau rendah hati (Madjid, 2013). Penilaian komunikasi lisan dilakukan menggunakan lembar observasi dengan mengamati keseluruh aspek komunikasi yang disusun menjadi 10 indikator dengan skala 0 sampai dengan 3. Penilaian komunikasi lisan dilakukan oleh dua orang dosen dengan menilai presentasi proyek dari mahasiswa.

Penilaian komunikasi tulisan mahasiswa dilakukan menggunakan portofolio dengan mengamati dua aspek yaitu dapat dimengerti dan kejelasan, sedangkan aspek 
menghormati, empati, dan rendah hati dirasa sulit untuk diukur mengingat ketiga aspek merupakan aspek komunikasi nonverbal. Dari aspek-aspek pengamatan, dibuat 5 butir indikator penilaian dengan skala 0 sampai dengan 3 berdasarkan rubrik yang telah dibuat. Penilaian komunikasi tulisan dilakukan oleh dua orang dosen dengan menilai tiga laporan mingguan dan satu laporan akhir. Adapun kisi-kisi instrumen untuk penilaian komunikasi lisan dan tulisan dapat dilihat pada Tabel 1.

Tabel 1 Kisi-Kisi Instrumen Penilaian Komunikasi Lisan dan Tulisan

\begin{tabular}{|c|c|c|}
\hline Variabel & Aspek & Indikator \\
\hline \multirow{5}{*}{$\begin{array}{l}\text { Rubik Penilaian } \\
\text { Komunikasi Lisan }\end{array}$} & Menghormati & $\begin{array}{l}\text { a. Perhatian ke pendengar } \\
\text { b. Sikap ke pendengar }\end{array}$ \\
\hline & Empati & $\begin{array}{l}\text { a. Mendengarkan pendenar } \\
\text { b. Memahami pendengar }\end{array}$ \\
\hline & Dapat didengar & $\begin{array}{l}\text { a. Suara dalam menyampaikan pesan } \\
\text { b. Bahasa yang digunakan }\end{array}$ \\
\hline & Kejelasan & $\begin{array}{l}\text { a. Makna dari pesan } \\
\text { b. Tata bahasa }\end{array}$ \\
\hline & Rendah hati & $\begin{array}{l}\text { a. Kesopanan dari gestur } \\
\text { b. Kesopanan dari bahasa }\end{array}$ \\
\hline \multirow{2}{*}{$\begin{array}{l}\text { Rubrik Penilaian } \\
\text { Komunikasi } \\
\text { Tulisan }\end{array}$} & Dapat dimengerti & $\begin{array}{l}\text { a. Struktur kalimat } \\
\text { b. Struktur paragraf }\end{array}$ \\
\hline & Kejelasan & $\begin{array}{l}\text { a. Kalimat mudah dipahami } \\
\text { b. Menggunakan PUEBI } \\
\text { c. Hubungan antarparagraf }\end{array}$ \\
\hline
\end{tabular}

Teknik analisis data menggunakan statistik deskriptif dan inferensial. Statistik deskriptif digunakan untuk mengetahui gambaran umum kemampuan komunikasi mahasiswa dalam proyek desain website. Adapun untuk pengkategorian dalam penilitian dapat dilihat pada Tabel 2 (Arikunto, 2014).

\section{Tabel 2 Pengkategorian Nilai}

\begin{tabular}{cc}
\hline Rentang Nilai & Kategori \\
\hline $0-45$ & Kurang \\
$46-65$ & Cukup \\
$66-85$ & Baik \\
$86-100$ & Sangat Baik \\
\hline
\end{tabular}

Statistik inferensial menggunakan analisis multivariate untuk mengetahui ada tidaknya perbedaan kemampuan komunikasi lisan dan tulisan mahasiswa P.TIK 
dalam proyek desain website. Sebelum uji analisis tersebut, perlu dilakukan uji prasyarat yang terdiri dari uji normalitas, uji homogenitas, dan uji matriks varian kovarian.

\section{HASIL DAN PEMBAHASAN}

\section{Hasil}

Deskripsi kemampuan komunikasi tulisan mahasiswa pada proyek desain website dapat dilihat pada Tabel 3.

Tabel 3 Rata-Rata Kemampuan Komunikasi secara Tulisan Mahasiswa pada Proyek Desain Website

\begin{tabular}{llllll}
\hline \multirow{2}{*}{ Aspek } & \multicolumn{1}{c}{ Indikator } & \multicolumn{2}{c}{ BL } & \multicolumn{2}{c}{ F2F } \\
\cline { 3 - 6 } & & Mean & Std. Dev & Mean & Std. Dev \\
\hline Dapat & Struktur kalimat & 76,25 & 12,08 & 69,46 & 12,39 \\
dimengerti & Struktur paragraf & 79,38 & 8,69 & 68,39 & 13,22 \\
Kejelasan & Kalimat mudah dipahami & 77,71 & 9,82 & 68,82 & 12,81 \\
& Menggunakan PUEBI & 79,58 & 9,57 & 68,6 & 10,07 \\
& Hubungan antarparagraf & 80,63 & 12,02 & 72,69 & 11,33 \\
\hline & Rata-Rata & $\mathbf{7 8 , 8 1}$ & $\mathbf{5 , 1 3}$ & $\mathbf{6 9 , 5 9}$ & $\mathbf{5 , 5 0}$ \\
\hline
\end{tabular}

Berdasarkan Tabel 3, diketahui rata-rata komunikasi secara tulisan pada kelas yang menerapkan BL adalah 78,81 atau masuk dalam kategori baik, sementara ratarata pada kelas yang menerapkan F2F adalah 69,59 atau masuk dalam kategori baik. Dari lima indikator yang digunakan untuk mengukur kemampuan komunikai secara tulisan, rata-rata kemampuan komunikai tulisan pada kelas BL berada pada rentang 75 hingga 80, sedangkan pada kelas F2F rata-rata kemampuan komunikasi tulisan kurang dari 70, kecuali pada indikator hubungan antarparagraf yang memperoleh skor rata-rata lebih dari 70 .

Deskripsi kemampuan komunikasi lisan mahasiswa pada proyek desain website dapat dilihat pada Tabel 4 . 
Tabel 4 Rata-Rata Kemampuan Komunikasi secara Lisan Mahasiswa pada Proyek Desain Website

\begin{tabular}{llcccc}
\hline \multirow{2}{*}{ Aspek } & \multicolumn{1}{c}{ Indikator } & \multicolumn{2}{c}{ BL } & \multicolumn{2}{c}{ F2F } \\
\cline { 2 - 6 } & & Mean & Std. Dev & Mean & Std. Dev \\
\hline Menghormati & Perhatian ke pendengar & 78,13 & 10,36 & 77,42 & 12,33 \\
\multirow{2}{*}{ Empati } & Sikap ke pendengar & 75,00 & 13,82 & 77,78 & 9,51 \\
& Mendengarkan & 75,00 & 11,97 & 75,63 & 11,62 \\
& pendengar & & & & \\
Dapat & Memahami pendengar & 70,14 & 12,12 & 68,82 & 10,88 \\
didengar & Suara dalam & 77,43 & 13,68 & 76,7 & 5,25 \\
\multirow{2}{*}{ Kejelasan } & menyampaikan pesan & & & & \\
& Bahasa yang digunakan & 77,78 & 13,54 & 76,34 & 11,95 \\
Rendah hati & Makna dari pesan & 74,65 & 12,38 & 74,91 & 7,57 \\
& Tata bahasa & 76,74 & 11,42 & 78,85 & 9,23 \\
& Kesopanan dari gestur & 77,43 & 11,80 & 73,12 & 9,42 \\
& Kesopanan dari bahasa & 76,04 & 16,48 & 74,91 & 9,83 \\
\hline & Rata-Rata & $\mathbf{7 5 , 8 3}$ & $\mathbf{5 , 3 6}$ & $\mathbf{7 5 , 4 5}$ & $\mathbf{4 , 0 8}$ \\
\hline
\end{tabular}

Berdasarkan Tabel 4, diketahui rata-rata komunikasi secara lisan pada kelas yang menerapkan BL adalah 75,83 atau masuk dalam kategori baik, sementara ratarata pada kelas yang menerapkan $\mathrm{F} 2 \mathrm{~F}$ adalah 75,45 atau masuk dalam kategori baik. Dari sepuluh indikator yang digunakan untuk mengukur kemampuan komunikai secara tulisan, rata-rata kemampuan komunikai tulisan pada kelas BL berada lebih dari 70. Hal yang sama juga terlihat pada kelas F2F, rata-rata kemampuan komunikasi tulisan berada lebih dari 70, kecuali pada indikator memahami pendengar yang memperoleh skor rata-rata kurang dari 70.

Terdapat atau tidaknya perbedaan kemampuan komunikasi mahasiswa pada proyek desain website pada kelas yang menerapkan BL dan F2F dapat diukur dengan melakukan pengujian multivariat (MANOVA). Sebelum melakukan pengujian MANOVA perlu dilakukan uji prasyarat yang terdiri dari uji normalitas, uji homogenitas, dan uji matriks varian kovarian.

Tabel 5 Uji Normalitas Data

\begin{tabular}{lccc}
\hline Variabel & Kolmogorov & Sig & Kesimpulan \\
\hline Lisan & 1,199 & 0,113 & Normal \\
Tulisan & 0,642 & 0,805 & Normal \\
\hline
\end{tabular}


Berdasarkan uji normalitas pada Tabel 5, diketahui bahwa nilai signifikansi seluruh data lebih besar atau sama dengan 0,05 yang artinya data berdistribusi normal dan pengujian dapat dilakukan dengan statistik parametrik.

Tabel 6 Uji Homogenitas Data

\begin{tabular}{lcccc}
\hline Variabel & df1 & df2 & Sig & Kesimpulan \\
\hline Lisan & 1 & 61 & 0,501 & Homogen \\
Tulisan & 1 & 61 & 0,644 & Homogen \\
\hline
\end{tabular}

Berdasarkan uji homogenitas pada Tabel 6 diketahui bahwa seluruh data berada pada kelompok yang homogen karena nilai signifikansi lebih besar atau sama dengan 0,05. Artinya, kedua kelompok berasal dari kelompok yang sama dan dapat dilakukan pengujian secara univariat.

Tabel 7 Uji Matriks Varian Kovarian

\begin{tabular}{lcccc}
\hline Box's M & df1 & df2 & Sig & Kesimpulan \\
\hline Lisan & 3 & 693137 & 0,185 & Homogen \\
\hline
\end{tabular}

Berdasarkan uji matriks kovarian pada Tabel 7, diketahui bahwa matrik varians kovarian berada pada kelompok yang homogen karena nilai signifikansi lebih besar atau sama dengan 0,05 . Oleh karenanya, ketiga uji prasyarat, yaitu uji normalitas, uji homogentias, dan uji matriks varian kovarian terpenuhi, maka pengujian MANOVA dapat dilakukan.

Tabel 8 Uji MANOVA Komunikasi Mahasiswa

\begin{tabular}{llcc}
\hline \multicolumn{1}{c}{ Effect } & F & Sig \\
\hline Kelas & Pillai's Trace & 22,954 & 0,00 \\
& Wilks' Lambda & 22,954 & 0,00 \\
& Hotelling's Trace & 22,954 & 0,00 \\
& Roy's Largest Root & 22,954 & 0,00 \\
\hline
\end{tabular}

Berdasarkan Tabel 8, diketahui bahwa model pembelajaran pada pengujian Pillai's Trace, Wilks' Lambada, Hotelling's Trace, dan Roy's Largest Root. memiliki nilai signifikansi sebesar 0,000 kurang dari atau sama dengan 0,05 atau lebih kecil dari taraf signifikansi Hal tersebut berarti terdapat perbedaan rata-rata komunikasi lisan dan tulisan yang signifikan berdasarkan model pembelajaran yang diterapkan. 
Selanjutnya pengujian dilakukan dengan uji univariat untuk melihat pengaruh pada model pembelajaran untuk setiap komunikasi. Hasil pengujian univariat dapat dilihat pada Tabel 9.

Tabel 9 Uji Univariat Komunikasi Mahasiswa

\begin{tabular}{llcc}
\hline & Variabel & F & Sig \\
\hline \multirow{2}{*}{ Kelas } & Lisan & 0,006 & 0,94 \\
& Tulisan & 46,294 & 0,00 \\
\hline
\end{tabular}

Berdasarkan Tabel 9 diketahui bahwa nilai signifikan pada kemampuan komunikasi secara lisan adalah 0,94 lebih besar dan atau sama dengan 0,05 yang berarti tidak terdapat perbedaan kemampuan komunikasi lisan yang signifikan antara kelas yang menerapkan BL dan kelas yang menerapkan F2F. Sedangkan nilai signifikansi pada kemampuan komunikasi secara tulisan adalah 0,00 yang berarti terdapat perbedaan kemampuan komunikasi tulisan yang signfiikan antara kelas yang menerapkan BL dan kelas yang menerapkan F2F.

\section{Pembahasan}

Berdasarkan hasil penelitian, diketahui bahwa kemampuan komunikasi mahasiswa pada proyek desain website secara umum tergolong baik. Hal tersebut berarti melalui proyek website, kemampuan komunikasi mahasiswa dapat ditingkatkan. Hasil penelitian sesuai dengan berbagai penelitian lainnya yang menunjukkan bahwa pembelajaran berbasis proyek dapat meningkatkan kemampuan komunikasi peserta didik (Saenab, et al., 2018). Pembelajaran berbasis proyek mempromosikan pembelajaran yang mendorong peserta didik untuk menjadi komunikator yang efektif dan beradaptasi diberbagai lingkungan yang berbeda (Alves, et al., 2017).

Proses peningkatan kemampuan komunikasi dalam pembelajaran berbasis proyek, berlangsung mulai tahap awal hingga tahap akhir pengerjaan proyek (Sabirin, 2016). Proses peningkatan kemampuan komunikasi terjadi pada saat mahasiswa menyampaikan rencana proyek, dalam kegiatan tersebut mahasiswa melakukan diskusi dengan dosen maupun dengan mahasiswa lain. Mahasiswa akan melakukan analisis permasalahan nyata. Selanjutnya, mahasiswa melaksanakan proyek, pada 
tahap proses komunikasi terjadi lebih intens antarmahasiswa dengan mahasiswa lainnya dalam kelompok untuk membahas pengerjaan proyek ataupun dengan dosen pengampu mata kuliah untuk mendiskusikan terkait kemajuan proyek. Pada tahap akhir, mahasiswa perlu mempresentasikan proyek yang dikerjakan kepada dosen, mahasiswa satu kelas, dan mahasiswa lainnya.

Proyek desain website, mahasiswa tidak hanya dilatih untuk melakukan komunikasi secara lisan tetapi juga secara tulisan. Komunikasi secara lisan dilatih melalui kegiatan-kegiatan seperti diskusi, presentasi, maupun konsultasi dengan rekan mahasiswa, dosen, ataupun pihak-pihak lain yang terkait dengan proyek yang dikerjakan. Sementara komunikasi secara tulisan, dilatih melalui kegiatan-kegiatan seperti pembuatan catatan harian, pembuatan media presentasi, dan laporan akhir proyek.

Penelitian juga bertujuan melihat ada tidaknya pengaruh penerapan BL dan F2F pada proyek desain website terhadap kemampuan komunikasi mahasiswa. Dari hasil penelitian diketahui bahwa penerapan BL dan F2F memberikan perngaruh yang berbeda terhadap kemampuan komunikasi mahasiswa pada proyek desain website. Penelitian yang dilakukan sesuai dengan beberapa penelitian sebelumnya yang menunjukkan adanya perbedaan kemampuan komunikasi pada kelompok yang menerapkan BL dan kelompok yang menerapkan F2F (Dziuban, et al., 2018; Sriarunrasmee, et al., 2015, Hinampas, et al., 2018), meskipun beberapa penelitian menunjukkan tidak adanya perbedaan kemampuan komunikasi pada kelompok yang menerapkan BL dan kelompok yang menerapkan F2F (Susilowati and Latifa, 2016; Evtyugina, et al., 2016).

Berdasarkan hasil penelitian, terlihat bahwa penerapan BL memberikan pengaruh yang lebih baik dari pada F2F pada kemampuan komunikasi secara tulisan sementara pada komunikasi secara lisan diketahui bahwa tidak ada perbedaan yang signifikan. Penelitian lain menyatakan bahwa penerapan BL memberikan dampak positif berupa kinerja yang lebih baik dalam hal komunikasi secara tulisan (Permana, 2017; Rahman, 2018). Hasil penelitian menunjukkan bahwa BL tetap memberikan mahasiswa kemampuan komunikasi secara lisan yang dipraktikkan dalam perkuliahan secara konvensional, penilaian terhadap komunikasi secara lisan 
dilakukan pada saat mahasiswa melakukan presentasi. Artinya, hasil penelitian memperlihatkan bahwa mahasiswa yang menerapkan BL mendapatkan keunggulan dari pembelajaran secara F2F dan secara online (Lalima and Dangwal, 2017).

Perbedaan pada kemampuan komunikasi secara tulisan pada kelompok BL dan F2F terjadi dikarenakan keunggulan yang diterapkan pada BL. Melalaui BL, dosen dapat melakukan review atau memberikan masukan terlebih dahulu terhadap catatan harian ataupun laporan yang dikerjakan mahasiswa, sementara pada F2F, review baru dilaksanakan pada saat di kelas, sehingga mahasiswa tidak memiliki waktu yang cukup untuk memperbaiki catatan harian ataupun laporan yang dihasilkan. Melalui BL, memungkinkan adanya umpan balik langsung dari sesama mahasiswa ataupun dari dosen (Smith, 2015; Jeffrey, et al., 2014). Penerapan BL membantu mahasiswa dalam menerapkan cara-cara baru berkomunikasi dan meningkatkan kualitas interaksi antara dosen dengan mahasiswa ataupun mahasiswa dengan mahasiswa yang difasilitasi dengan teknologi (Zhang and Zhu, 2017; Huang, 2016)-

\section{SIMPULAN}

Berdasarkan hasil penelitian, dapat disimpulkan bahwa kemampuan komunikasi secara lisan maupun tulisan pada proyek desain website berada pada kategori baik, yang artinya pembelajaran berupa proyek desain website mampu mempromosikan kemampuan komunikasi secara lisan maupun tulisan dengan baik. Dari penerapan BL dan F2F pada proyek desain website, terlihat bahwa tidak ada perbedaan kemampuan komunikasi secara lisan pada kedua kelompok tersebut, tetapi pada kemampuan komunikasi secara tulisan, kelompok yang menerapkan BL lebih baik dari pada kelompok yang menerapkan F2F.

\section{UCAPAN TERIMA KASIH}

Ucapan terima kasih diucapkan kepada LPPM IKIP PGRI Pontianak yang telah memberi bantuan dana untuk melaksanakan penelitian tahun 2019 sesuai dengan nomor dokumen 003/L.202/PK/III/2019 dan Program Studi P.TIK IKIP PGRI Pontianak sebagai tempat pelaksanaan penelitian. 


\section{DAFTAR PUSTAKA}

Abbas, L. 2015. Applying Blended Learning to English Communication Courses 101 and 102 at BZU/Palestine (Case Study). Palestinian Journal of Open Education, 5(9): 31-64.

Afriana, J., Permanasari, A., \& Fitriani, A. 2016. Project Based Learning Integrated to STEM to Enhance Elementary School's Students Scientific Literacy. Jurnal Pendidikan IPA Indonesia, 5(2): 261-267.

Ahmed, F. \& Capretz, L. F. 2012. Soft Skills Requirements in Software Development Jobs: A Cross-Cultural Emperical Study. Journal System and IT, 14(1): 58-81.

Ahmed, F., Capretz, L. F., Bouktif, S., \& Campbell, P. 2013. Soft Skills and Software Development: A Reflection from Software Industry. International Journal of Information Processing and Management, 4(3): 171-191.

Alves, A.C., Leão, C.P., Moreira, F., \& Teixeira, S. 2017. Project-Based Learning and Its Effects on Freshmen Social Skills in an Engineering Program dalam Otero-Mateo, Manuel \& Pastor-Fernandez, Andres (Editor). Human Capital and Competences in Project Management. London: IntechOpen.

Arikunto, S. 2014. Evaluasi Program Pendidikan. Jakarta: Bumi Aksara.

Dziuban, C., Graham, C., Mokal, P., Norberg, A., \& Sicilia, N. 2018. Blended Learning: The New Normal and Emerging Technologies. International Journal of Educational Technology in Higher Education, 15(3): 1-16.

Eggleston, A. G. \& Rabb, R. J. 2018.Technical Communication for Engineers: Improving Professional and Technical Skills. Proceedings of the American Society for Enggineering Education 2018 Annual Conference, Salt Lake City: Juni 2018. Hal: 118-129.

Evtyugina, A. A., Simonova, M. V., \& Fedorenko, R. V. 2016. Teaching Conversational Language Skills to Foreign Students: Blended Learning and Interactive Approaches. IEJME-mathematics Education, 11(8): 2925-2936.

Ghahari, S. 2013. The Effect of Blended Learning vs. Classroom Learning Techniques on Iranian EFL Learners' Writing. International Journal of Foreign Language Teaching \& Research, 1(3): 77-86.

Harahap, F., Nasution, N. E. A., \& Manurung, B. 2019. The Effect of Blended Learning on Student's Learning Achievement and Science Process Skills in Plant Tissue Culture Course. International Journal of Instruction, 12(1): 521-538.

Hinampas, R. T., Murillo, C., Tan, D., \& Layosa, R. 2018. Blended Learning Approach: Effect on Students' Academic Achievement and Practical Skills in Science Laboratories. International Journal of Scientific \& Technology Research, 7(11): 63-69.

Huang, Q. 2016. Learners' Perception of Blended Learning and the Roles and Interaction of F2F and Online Learning. ORTESOL Journal, 33(2016): 1433.

Jeffrey, L. M., Milne, J., \& Suddaby, G. 2014. Blended Learning: How Teachers Balance the Blend of Online and Classroom Components. Journal of Information Technology Education: Research, 13(2014): 121-140. 
Kashefi, H., Ismail, Z., \& Yusof, M. Y. 2012. The Impact of Blended Learning on Communication Skills and Teamwork of Engineering Students in Multivariable Calculus. Procedia-Social and Behaviorial Science, 56(2012): 341-347.

Kovalyova, Y. Y., Soboleva, A. V., \& Kerimkulov, A. T. 2016. Project Based Learning in Teaching Communication Skills in English as a Foreign Language to Engineering Students. International Journal of Emerging Technologies in Learning, 11(4): 153-164.

Lalima \& Dangwal, K. L. 2017. Blended Learning: An Innovative Approach. Universal Journal of Educational Research, 5(1): 129-136.

Lesmana, C. \& Arpan, M. 2017. Penerapan Model Project Based Learning terhadap Kemampuan Psikomotor, Aktivitas Belajar, dan Respon Mahasiswa. Jurnal Pendidikan Informatika dan Sains, 6(1): 8-19.

Madjid, A. 2013. Strategi Pembelajaran. Bandung: PT Remaja Rosdakarya.

Morton, C., Saleh, S., Smith, S., Hemani, A., Ameen, A., Bennie, T., \& ToroTroconis, M. 2016. Blended Learning: How can We Optimise Undergraduate Student Engagement? BMC Medical Education, 16(195): 18.

Musa, F., Mufti, N., Latiff, R. A., \& Amin, M. M. 2012. Project-Based Learning (PjBL): Inculcating Soft Skills in $21^{\text {st }}$ Century Workplace. Procedia-Social and Behaviorial Science, 59(2012): 565-573.

Onong, U. E. 2000. Ilmu, Teori, dan Filsafat Komunikasi. Bandung: Citra Aditya Bakti.

Permana, G. Y. 2017. The Effect of Using Blended Learning Strategy toward the 8 Grade Students' Writing Competency. Journal of Psychology and Instruction, 1(2): 79-87.

Rahman, A. M. 2018. English Writing Performance Using Blended Learning in TVET Education. Language Literacy, 2(1): 28-36.

Sabirin, F. 2016. Peningkatan Kreativitas dan Kolaborasi Mahasiswa melalui Pembelajaran Berbasis Proyek pada Mata Kuliah Pemrograman di Politeknik Negeri Pontianak. Jurnal Pendidikan Informatika dan Sains, 5(2): 195-211.

Saenab, S., Yunus, S. R., Saleh, A. R., Virninda, A. N., Hamka, L., \& Sofyan, N. A. 2018. Project-Based Learning as the Atmosphere for Promoting Students' Communication Skills. Journal of Physics: Conference Series, 1028(2018): 012026.

Smith, C. M. 2015. Implementing and Evaluating a Blended Learning Format in the Communication Interhsip Course. Journal of Information Technology Education: Innovations in Practice, 14(1): 271-235.

Snodin, N. S. 2013. The Effects of blended Learning with a CMS on the Development of Autonomous Learning: A Case Study of Different Degrees of Autonomy Achieved by Individual Learners. Computers \& Education, 61(1): 209-216.

Sriarunrasmee, J., Techataweewan, W., \& Mebusaya, R. P. 2015. Blended Learning Supporting Self-Directed Learning and Communication Skills of 
Srinakharinwirot University's First Year Students. Procedia - Social and Behavorial Sciences, 197(2015): 1564-1569.

Sumarni, W. 2015. The Strengths and Weaknesses of the Implementation of Project Based Learning: A Review. International Journal of Science and Research, 4(3): 478-484.

Susilowati, N., \& Latifah, L. 2016. The Implementation Effect Blended Learning Approach on Accounting Knowledge and Generic Skills. Journal of Accounting and Business Education, 1(1): 66-76.

Trisdiono, H. 2014. Project-Based Learning in Teachers' Perspectives. DIJE, 2(5): 34-40.

Udacity. 2017. Ulitmate Skills Checklist for Your First Front-End Develper Job dalam https://www.udacity.com/wp-content/uploads/2015/03/UdacityUltimateFront-EndWebDeveloperCareerGuide.pdf. Diakses 8 Februari 2019.

Vernandakis, N., Giannousi, M., Derri, V., Michalopoulos, M., \& Kioumourtzoglou, E. 2012. The Impact of Blended and Traditional Instruction in Student's Performance. Procedia Technology, 1(2012): 439443.

Wagner, T. 2010. Overcoming The Global Achievement Gap. Cambridge, Mass: Harvard University.

World Economic Forum. 2016. Chapter 1: The future of jobs and skills. Diakses dari http://reports.weforum.org/future-of-jobs-2016/chapter-1-the-future-ofjobsand-skills. Diakses 10 Febrari 2019.

Zhang, W. \& Zhu, C. 2017. Review on Blended Learning: Indentifying the Key Themes and Categories. International Journal of Information and Education Technology, 7(9): 673-678.

Zou, J. P. 2005. E-Learning New World-Internet and Learning. Taipei, Taiwan: Tingmao. 